\title{
EFEKTIFITAS SELF-MANAGEMENT PROGRAM DALAM MENGELOLA STRES BELAJAR SISWA DI SMA NEGERI 2 BANJARMASIN
}

\author{
Salawatil Jannah \\ SMA Negeri 2 Banjarmasin
}

\begin{abstract}
ABSTRAK
Tujuan penelitian ini adalah untuk mengetahui gambaran tingkat stres belajar sebelum dan sesudah diberikan konseling dengan teknik self-management program pada siswa kelas akselerasi, serta untuk mengetahui efektivitas teknik konseling ini dalam mengelola stres belajar siswa kelas akselerasi di SMA Negeri 2 Banjarmasin. Penelitian ini merupakan penelitian kuantitatif dengan menggunakan metode eksperimen yang dilaksanakan di SMA Negeri 2 Banjarmasin. Populasi dalam penelitian ini adalah siswa kelas X MIPA dan XI MIPA. Sampel pada penelitian ini diperoleh melalui kriteria inklusi dengan menggunakan teknik stratified sampling purposive yang berjumlah 10 orang. Teknik analisis data menggunakan rumus t-test. Berdasarkan pengujian dari data yang didapatkan thit $>\operatorname{ttab}(3,71>1,86)$ maka Ho ditolak, yang artinya ada perbedaan tingkat persentasi stres siswa sebelum diberikan konseling dengan menggunakan teknik self-management program dan sesudah diberikan konseling.
\end{abstract}

Kata Kunci: self management, stres belajar

\section{PENDAHULUAN}

Fenomena stres pada umumnya, sering diartikan oleh masyarakat sebagai suatu "tidak waras". Menurut Robert S. Feldman (1989) dalam Fausiah, Fitri (2006: 9-10), stres adalah suatu proses yang mengancam, menantang, ataupun membahayakan dan individu merespon peristiwa itu pada level fisiologis, emosional, kognitif dan perilaku. Peristiwa yang memunculkan stres dapat saja positif (misalnya merencanakan perkawinan) atau negatif (misalnya kematian keluarga).

Layaknya fenomena stres yang terjadi di masyarakat, di lingkungan sekolah pun para siswa cenderung mengalami stres. Stres yang terjadi pada siswa tak lepas dari masalah belajar mereka. Siswa sering merasa terbebani dengan materi pelajaran dan tugas yang banyak serta harus mengikuti sejumlah ulangan atau tes yang cenderung menuntut siswa mendapatkan nilai yang memenuhi standar yang telah ditentukan. Penelitian ini didukung dari suatu hasil penelitian yang dilakukan oleh
Aryani, Farida (2008: 6) yang memaparkan bahwa masa remaja merupakan masa dimana seorang anak lebih banyak mengalami stres. Jenis stres yang banyak dialami anak pada masa remaja ini yaitu stres belajar yang berkaitan dengan strategi belajar (mengelola waktu belajar). Stres belajar yang terjadi pada siswa ini berpengaruh pada proses belajar dan ketidaksiapan siswa dalam menghadapi ulangan dan ujian di sekolah. Penelitian ini didukung oleh penelitian Wisantyo, Nurmalitasari Indah (2010: 23) yang menjelaskan bahwa pada rata-rata sampel penelitian yang dilakukannya di SMAN Semarang menyatakan stres belajar yang dialami siswa memiliki nilai stres 83,31\% pada kelas reguler, $78 \%$ pada kelas olimpiade, dan 89,5\% pada kelas akselerasi. Penelitian ini menunjukkan bahwa stres belajar yang dialami siswa terdapat pada kelas reguler.

Stres merupakan keadaan individu yang dipengaruhi oleh rangsangan dari dalam maupun dari luar individu yang 
menimbulkan reaksi secara fisik maupun psikologis. Faktor penyebab stres dapat dibedakan menjadi dua, yaitu faktor eksternal dan internal. Salah satu faktor stres siswa yang merupakan faktor eksternal yaitu stres akademik yaitu hal yang meliputi kegiatan belajar siswa. Penelitian ini didukung dari hasil penelitian Nanwani (2010: 1) bahwa stres yang dialami siswa merupakan stres yang didasari faktor eksternal yaitu stres akademik. Dalam penelitiannya, didapat hasil bahwa $80 \%$ siswa kadang-kadang jenuh mengikuti 9 jam pelajaran dalam sehari, $38 \%$ siswa mnegikuti kegiatan les yang tidak disukainya setelah pulang sekolah, $47 \%$ siswa merasakan jantung berdebar-debar saat maju ke depan kelas, $53 \%$ siswa merasa berat hati untuk mempelajari pelajaran yang tidak disukainya, dan $47 \%$ siswa selalu merasa orang tuanya akan bangga jika ia mendapat nilai di atas 80 . Dari hasil-hasil tersebut ditunjukkan bahwa siswa mengalami stres karena tuntutan akademik.

Berbagai akibat dirasakan oleh siswa dari adanya stres yang mereka alami. Dampak tersebut bukan saja mereka rasakan pada kegiatan belajar, tetapi juga berdampak pada persiapan siswa dalam menghadapi ujian sekolah. Hal ini dapat dilihat seperti halnya yang dipaparkan oleh Susilo (Kompas: 2009) bahwa seorang anak stres dalam mengerjakan soal-soal UN matematika. Stres siswa itu dapat dilihat ketika anak tersebut menangis saat keluar dari ruangan ujian. Akibat stres tersebut seusai menghadapi UN, kepercayaan diri siswa pun menurun. Terlepas dari dampak stres pada psikologi siswa, dampak stres juga dapat dilihat dari sisi biologis siswa. Seperti halnya yang dipaparkan Sudirman (Radar Tasikmalaya: 2010) bahwa sebanyak 15 siswa SMK Farmasi Bhakti Kencana Ciamis menderita sakit flu dan pilek sejak hari pertama pelaksanaan Ujian Nasional. Mereka diduga stres saat menjawab materi soal yang diujiankan. Akibat stres yang siswa rasakan, perasaan tegang pun selau dirasakan siswa saat melaksanakan ujian dari pertama sampai hari terakhir.

Berkaitan dengan kondisi siswa di SMA Negeri 2 Banjarmasin yang menerapkan konsep fullday, serta dengan adanya beban belajar anak yang sangat padat, adanya tuntutan orang tua yang berlebihan, membuat siswa kelas MIPA memiliki kecenderungan lebih tinggi untuk mengalami stres belajar yang mana stres belajar ini dapat berdampak negatif bukan hanya pada perkembangan psikologis serta prestasi belajar siswa. Kondisi tersebut membuat penulis tertarik untuk melakukan penelitian di SMA Negeri 2 Banjarmasin, selain itu, alasan peneliti adalah selama ini masih kurang penelitian-penelitian stres belajar pada sekolah yang menerapkan pola fullday school. Dengan fenomena tersebut, perlu dikembangkan model mengelola stres untuk membantu siswa guna mengatasi stres belajar siswa. Salah satu hal yang dapat dilakukan siswa dalam menanggulangi atau mengelola stres belajar yang dialami yaitu dengan memanajemen diri mereka sendiri. Karena pada dasarnya stres bersifat kompleks, yaitu mencakup fisik dan psikis maka manajemen diri adalah salah satu cara yang tepat dalam mengelola stres belajar yang sering kali dialami siswa.

Penelitian dengan menggunakan self-management program ini didukung jurnal penelitian dari Takwin (2008: 11-12) yang menjelaskan bahwa self-management program merupakan aktivitas dalam memahami dan mengenali lingkup diri sendiri. Dengan self-management program, diri membentuk kompleksitas yang makin tinggi sehingga pertentangan dalam diri dapat diselesaikan dan sekaligus juga mengembangkan diri sebab aktualisasi dari potensi-potensi yang ada pada individu dapat berlangsung terus.

Dari adanya peranan teknik selfmanagement program yang telah dijelaskan, 
Jurnal Inovasi BK, Volume 2, Nomor 1 Juni 2020 yang mana teknik ini sebelumnya belum pernah diterapkan konselor sebagai teknik untuk mengatasi masalah belajar siswa di sekolah SMA Negeri 2 Banjarmasin, diharapkan dengan adanya teknik ini permasalahan siswa tentang belajar yang dapat menjadi penyebab timbulnya stres belajar dapat terkelola dengan baik. Karena pada dasarnya, stres belajar yang dialami siswa tidak hanya dapat berdampak negatif, namun juga dapat pula berdampak positif bagi siswa apabila taraf stres tersebut berada pada taraf yang seimbang. Oleh karena itu, apabila stres siswa dapat terkelola dengan baik maka diharapkan tuntutan belajar yang dialami siswa yang dapat menjadi penyebab terjadinya stres dapat bersifat positif.

Berdasarkan uraian tersebut, peneliti tertarik untuk meneliti stres belajar siswa menggunakan self-management program dengan menarik judul " Efektivitas SelfManagement Program dalam Mengelola Stres Belajar Siswa di SMA Negeri 2 Banjarmasin".

\section{METODE}

Jenis penelitian dalam penelitian ini adalah penelitian kuantitatif dengan rancangan penelitian eksperimen. Sugiyono (2011: 107), metode eksperimen berarti metode percobaan dengan memberikan perlakuan atau treatment pada variabel tertentu. Menurut Krathwohl (1997) dalam Nana Syaodih (2010: 57), metode penelitian eksperimen bersifat validation atau menguji, yaitu menguji pengaruh satu atau lebih variabel terhadap variabel lain. Penelitian ini menggunakan rancangan penelitian yaitu pre-eksperimental design, dengan bentuk desain Intact-Group Comparison, yaitu di dalam desain ini terdapat satu kelompok yang digunakan untuk penelitian, tetapi dibagi menjadi dua yaitu satu kelompok untuk eksperimen (yang diberi perlakuan) dan setengah untuk kelompok kontrol (yang tidak diberikan perlakuan).

\section{HASIL DAN PEMBAHASAN}

Berdasarkan hasil penggalian data yang terkumpul dengan menggunakan angket mengenai stres belajar yang dibagikan kepada 14 siswa kelas X MIPA dan 13 siswa kelas XI MIPA SMA Negeri 2 Banjarmasin. Kemudian data yang diperoleh diolah secara statistik guna mendapatkan hasil skala pengukuran stres belajar siswa. Dalam penelitian ini, mengklasifikasikan subyek penelitian menjadi lima kategori, yaitu sangat rendah, rendah, sedang, tinggi dan sangat tinggi. Pengklasifikasian tersebut diperoleh dengan membuat urutan total skor yang didapat subyek ke dalam bentuk interval (\%). Total skor dalam bentuk persen (\%) dibuat berdasarkan skor tertinggi dan terendah.

Skala pengukuran stres belajar memiliki 40 item pernyataan dengan 1-5 gradasi untuk menginterpretasikan dapat dibuat persentase skor dengan cara menjumlahkan skor-skor yang diperoleh, dibagi dengan 200 (jumlah item dikali jumlah gradasi) dikalikan dengan 100\%. Selanjutnya dalam menginterpretasikan persentase skor dalam kategori sangat rendah, rendah, sedang, tinggi, dan sangat tinggi.

Berdasarkan hasil perhitungan tersebut, maka diperoleh hasil skala pengukuran stres belajar siswa (pre-test) adalah sebagai berikut :

Hasil Pengukuran Skala Stres Belajar Kelas X MIPA SMA Negeri 2 Banjarmasin

\begin{tabular}{cccc}
\hline $\begin{array}{c}\text { No. } \\
\text { Konseli }\end{array}$ & $\begin{array}{c}\text { Skor } \\
\text { Total }\end{array}$ & $\%$ & $\begin{array}{c}\text { Kategori } \\
\text { Tingkat Stres }\end{array}$ \\
\hline X-1. & 85 & $43 \%$ & Rendah \\
\hline X-2. & 111 & $56 \%$ & Sedang \\
\hline X-3. & 69 & $35 \%$ & Sangat Rendah \\
\hline X-4. & 118 & $59 \%$ & Sedang \\
\hline X-5. & 85 & $43 \%$ & Rendah \\
\hline X-6. & 94 & $47 \%$ & Rendah \\
\hline X-7. & 95 & $48 \%$ & Rendah \\
\hline X-8. & 79 & $40 \%$ & Rendah \\
\hline X-9. & 115 & $58 \%$ & Sedang \\
\hline
\end{tabular}




\begin{tabular}{cccl}
\hline $\mathrm{X}-10$. & 107 & $54 \%$ & Sedang \\
\hline $\mathrm{X}-11$. & 83 & $42 \%$ & Rendah \\
\hline $\mathrm{X}-12$. & 97 & $49 \%$ & Rendah \\
\hline $\mathrm{X}-13$. & 102 & $51 \%$ & Rendah \\
\hline $\mathrm{X}-14$. & 94 & $47 \%$ & Rendah \\
\hline
\end{tabular}

Hasil Pengukuran Skala Stres Belajar Kelas XI MIPA SMA Negeri 2 Banjarmasin

\begin{tabular}{cccc}
\hline $\begin{array}{c}\text { No. } \\
\text { Konseli }\end{array}$ & $\begin{array}{c}\text { Skor } \\
\text { Total }\end{array}$ & $\%$ & $\begin{array}{c}\text { Kategori } \\
\text { Tingkat } \\
\text { Stres }\end{array}$ \\
\hline XI-1. & 114 & $57 \%$ & Sedang \\
\hline XI-2. & 108 & $54 \%$ & Sedang \\
\hline XI-3. & 119 & $60 \%$ & Sedang \\
\hline XI-4. & 92 & $46 \%$ & Rendah \\
\hline XI-5. & 152 & $76 \%$ & Tinggi \\
\hline XI-6. & 99 & $50 \%$ & Rendah \\
\hline XI-7. & 123 & $62 \%$ & Sedang \\
\hline XI-8. & 100 & $50 \%$ & Rendah \\
\hline XI-9. & 114 & $57 \%$ & Sedang \\
\hline XI-10. & 97 & $49 \%$ & Rendah \\
\hline XI-11. & 88 & $44 \%$ & Rendah \\
\hline XI-12. & 90 & $45 \%$ & Rendah \\
\hline XI-13. & 97 & $49 \%$ & Rendah \\
\hline
\end{tabular}

Berdasarkan tabel hasil pengukuran skala stres belajar di atas, maka dapat diperoleh siswa yang mengalami stres belajar pada kelas X MIPA berjumlah 4 siswa yang mengalami stres belajar sedang, 9 siswa yang mengalami stres belajar rendah, dan 1 siswa yang mengalami stres belajar sangat rendah. Sedangkan pada hasil skala pengukuran stres belajar kelas XI MIPA, diperoleh 1 siswa yang mengalami stres belajar tinggi, 5 siswa yang mengalami stres belajar pada kategori sedang, dan 7 siswa yang mengalami stres belajar pada kategori rendah.

Sehingga dapat disimpulkan bahwa pada hasil skala pengukuran stres belajar pada siswa SMA Negeri 2 Banjarmasin, diperoleh hasil data yaitu 1 siswa yang mengalami stres belajar tinggi, 9 siswa yang mengalami stres belajar sedang, 16 siswa yang mengalami stres belajar rendah, dan 1 siswa yang mengalami stres belajar sangat rendah.

Persentase Skala Stres Belajar Siswa

\begin{tabular}{ccc}
\hline Kategori & Frekuensi & Persentase (\%) \\
\hline Sangat Rendah & 1 & $3,70 \%$ \\
\hline Rendah & 16 & $59,26 \%$ \\
\hline Sedang & 9 & $33,33 \%$ \\
\hline Tinggi & 1 & $3,70 \%$ \\
\hline Sangat Tinggi & 0 & $0 \%$
\end{tabular}

Berdasarkan tabel hasil persentase di atas, sebelum mengikuti konseling untuk para konseli yang diberikan treatment mempunyai persentase stres belajar dalam kategori tinggi dan sedang. Dari kelima konseli tersebut, penurunan stres belajar paling tinggi dialami oleh konseli K1.4 dari $76 \%$ hingga mencapai $54 \%$ dalam kategori stres belajar tingkat sedang. Sedangkan penurunan paling kecil dialami oleh konseli K1.3 dengan persentase $55 \%$ dalam kategori sedang. Untuk kelompok kontrol, semua konseli berada pada kategori sedang dan dari kelima konseli yang mengalami peningkatan stres belajar terdapat pada K1.1 yang awalnya sebesar $56 \%$ menjadi $58 \%$. Untuk lebih jelasnya perbedaan pre-test dan post-test skala stres belajar dengan teknik self-management program dapat dilihat pada diagram sebagai berikut :

Perbandingan Pre-Test dan Post-Test Kelompok Treatment Skala Stres Belajar

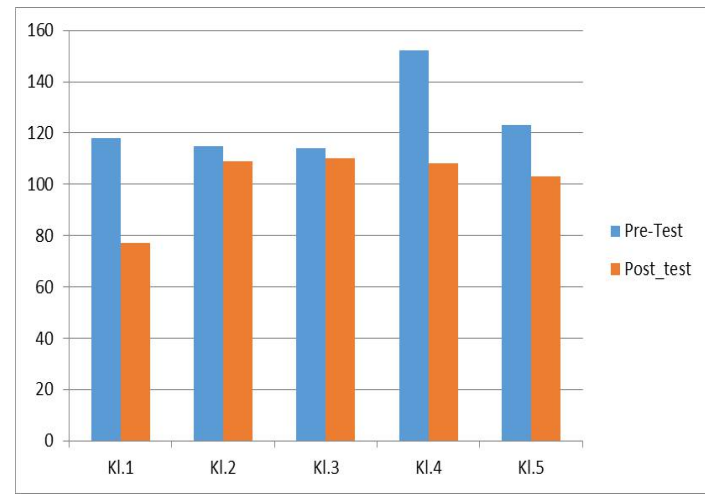

Berdasarkan gambar diagram diatas dapat terlihat penurunan tingkat stres belajar 
Jurnal Inovasi BK, Volume 2, Nomor 1 Juni 2020

konseli pada kelompok treatment dengan teknik self-management program. Penurunan tingkat gejala stres belajar pada konseli setelah dilakukan treatment itu juga di dukung dari adanya pernyataan konseli atas perubahan sikap dan gejala stres belajar yang konseli rasakan. Adapun pernyataan konseli pada lembar evaluasi pelaksanaan Self-Management Program di tahap akhir pertemuan ketiga, sebagai berikut :

Pernyataan Perubahan Sikap dan Gejala Stres Belajar

\begin{tabular}{|c|c|c|}
\hline Konseli & Aspek & Pernyataan \\
\hline \multirow{14}{*}{ K1.1 } & \multirow{9}{*}{$\begin{array}{l}\text { Perubahan } \\
\text { sikap yang } \\
\text { diharapkan }\end{array}$} & Perubahan \\
\hline & & sikap yang \\
\hline & & diharapkan \\
\hline & & adalah waktu \\
\hline & & belajar, hal \\
\hline & & sava canai \\
\hline & & dan saya \\
\hline & & lakukan \\
\hline & & dengan baik \\
\hline & \multirow{5}{*}{$\begin{array}{l}\text { Gejala } \\
\text { Stres }\end{array}$} & $\begin{array}{ll}\text { Iya, } & \text { rasa } \\
\text { stres } & \end{array}$ \\
\hline & & $\begin{array}{l}\text { stres pada } \\
\text { beberapa }\end{array}$ \\
\hline & & pelajaran \\
\hline & & telah \\
\hline & & berkurang. \\
\hline \multirow{11}{*}{$\mathrm{K} 1.2$} & \multirow{9}{*}{$\begin{array}{l}\text { Perubahan } \\
\text { sikap yang } \\
\text { diharapkan }\end{array}$} & Saya sudah \\
\hline & & dapat \\
\hline & & mengurangi \\
\hline & & bermain \\
\hline & & game, lebih \\
\hline & & teratur \\
\hline & & belajar, dan \\
\hline & & tidak stres \\
\hline & & belajar lagi \\
\hline & Gejala & Sudah \\
\hline & Stres & berkurang \\
\hline \multirow{5}{*}{ K1.3 } & \multirow{4}{*}{$\begin{array}{l}\text { Perubahan } \\
\text { sikap yang } \\
\text { diharapkan }\end{array}$} & $\begin{array}{l}\text { Mendapatkan } \\
\text { perilaku }\end{array}$ \\
\hline & & yang lebih \\
\hline & & dan dapat \\
\hline & & $\begin{array}{l}\text { mengontrol } \\
\text { waktu lebih }\end{array}$ \\
\hline & & \\
\hline
\end{tabular}

\begin{tabular}{|c|c|c|}
\hline & & efisien \\
\hline & $\begin{array}{l}\text { Gejala } \\
\text { Stres }\end{array}$ & $\begin{array}{l}\text { Ya, } \\
\text { berkurang } \\
\text { karena } \\
\text { adanya } \\
\text { jadwal } \\
\text { belajar } \\
\end{array}$ \\
\hline \multirow[t]{2}{*}{$\mathrm{K} 1.4$} & $\begin{array}{l}\text { Perubahan } \\
\text { sikap yang } \\
\text { diharapkan }\end{array}$ & $\begin{array}{l}\text { Ya, mampu } \\
\text { lebih } \\
\text { mengontrol } \\
\text { dan } \\
\text { menghargai } \\
\text { waktu }\end{array}$ \\
\hline & $\begin{array}{l}\text { Gejala } \\
\text { Stres }\end{array}$ & $\mathrm{Ya}$ \\
\hline \multirow[t]{2}{*}{ K1.5 } & $\begin{array}{l}\text { Perubahan } \\
\text { sikap yang } \\
\text { diharapkan }\end{array}$ & $\begin{array}{l}\text { Tidak sering } \\
\text { melamun, } \\
\text { tidak } \\
\text { menonton } \\
\text { TV, belajar } \\
\text { lebih } \\
\text { terorganisir }\end{array}$ \\
\hline & $\begin{array}{c}\text { Gejala } \\
\text { Stres }\end{array}$ & $\begin{array}{l}\text { Sedikit } \\
\text { berkurang }\end{array}$ \\
\hline
\end{tabular}

Tabel di atas merupakan pernyataan konseli yang terdapat pada lembar evaluasi yang diberikan konselor. Yang mana perubahan positif itu dinyatakan konseli dalam kurun waktu kurang lebih 9 hari dan dalam 3 kali pertemuan proses konseling dengan menggunakaan teknik selfmanagement program.

Hasil penelitian menunjukkan bahwa pelaksanaan konseling individual dengan menggunakan teknik selfmanagement program efektif dalam mengelola stres belajar siswa kelas akselerasi yang mana hal ini ditandai dengan adanya penurunan skor stres belajar. Adanya penurunan ini dapat terlihat pada skor stres belajar konseli yang pada awalnya sebelum diberikan perlakuan atau konseling, skor stres belajar konseli termasuk dalam kategori tinggi dan sedang, namun setelah diberikan konseling individual dengan teknik self-management program skor stres belajar konseli mengalami penurunan 
hingga termasuk dalam kategori sedang dan rendah.

Secara lebih spesifik hasil temuan di dalam proses konseling ini adalah pada konseli K1.1 (D.S) yang pada saat pre-test memiliki skor pada hasil skala stres belajar sebesar 59\% dalam kategori sedang mengalami penurunan skor stres belajar pada hasil post-test menjadi $39 \%$ dalam kategori rendah. Pada konseli K1.2 (ON), pada saat pre-test memiliki skor pada hasil skala stres belajar sebesar 58\% dalam kategori sedang mengalami penurunan skor stres belajar pada hasil post-test menjadi $55 \%$ dalam kategori sedang. Pada konseli Kl.3 (A), pada saat pre-test memiliki skor pada hasil skala stres belajar sebesar 57\% dalam kategori sedang mengalami penurunan skor stres belajar pada hasil posttest menjadi 55\% dalam kategori sedang. Pada konseli K1.4 (K.J), pada saat pre-test memiliki skor pada hasil skala stres belajar sebesar $76 \%$ dalam kategori tinggi mengalami penurunan skor stres belajar pada hasil post-test menjadi 54\% dalam kategori sedang. Pada konseli Kl.5 (F), pada saat pre-test memiliki skor pada hasil skala stres belajar sebesar $62 \%$ dalam kategori sedang mengalami penurunan skor stres belajar pada hasil post-test menjadi 52\% dalam kategori rendah. Dengan demikian dapat disimpulkan bahwa 5 konseli mengalami penurunan skor stres belajar yang berbeda-beda. Hal ini diperngaruhi dari adanya hambatan-hambatan baik dari pihak konsleor dan konseli. Dari konselor yaitu belum dapat sepenuhnya untuk menciptakan suasana yang efektif di dalam proses konseling. Sedangkan hambatan dari konseli, yaitu terlalu banyak bercanda dalam pelaksanaan proses konseling.

Dari hasil pembahasan pelaksanaan konseling individual dengan teknik selfmanagement program di atas, dapat disimpulkan bahwa konseling individual dengan teknik self-management program efektif dalam mengelola stres belajar siswa, yang ditandai dengan menurunnya skor stres belajar pada saat sebelum konseling dan setelah konseling individual.

\section{KESIMPULAN}

Berdasarkan hasil penelitian ini, maka dapat disimpulkan sebagai berikut :

1. Sebelum diberikan konseling individual skor rata-rata stres belajar sebesar $62,4 \%$ yang termasuk dalam kategori sedang.

2. Setelah diberikan treatment melalui proses konseling individual dengan teknik self-management program, stres belajar yang konseli alami mengalami penurunan menjadi $51 \%$ dalam kategori sedang.

3. Dari perhitungan T-Test menunjukkan thit sebesar 3,17 antara persentase kecemasan siswa sebelum dan sesudah konseling individual dengan nilai ttab sebesar 2,306 yang artinya terdapat perbedaan.

Dengan demikian dapat disimpulkan bahwa "Konseling individual dengan menggunakan teknik self-management program efektif dalam mengelola stres belajar siswa, yang ditandai dengan menurunnya persentase skala stres belajar siswa."

\section{DAFTAR PUSTAKA}

Aryani, Farida. 2008. Efektivitas Pendekatan Cognitive Behavior Modification (CBM) untuk Mengelola Stres Belajar Siswa di Kota Malang. Disertasi tidak diterbitkan. Malang. Program Pascasarjana Universitas Negeri Malang.

Fausiah, Fitri. \& Widury, Julianti. 2005. Psikologi Abnormal Klinis Dewasa. Jakarta: Universitas Indonesia (UIPress).

Nanwani, Anju Arjan. 2010. Faktor-faktor Penyebab Stres Akademik Pada 
Jurnal Inovasi BK,Volume 2, Nomor 1 Juni 2020

Siswa Kelas 5 Sd Jubile. Tesis tidak diterbitkan. Jakarta. Fakultas Keguruan Ilmu Pendidikan Unika Atma Jaya. (http://lib.atmajaya.ac.id/default.asp $\mathrm{x}$ ?tabID $=61 \& \mathrm{id}=186286 \& \mathrm{src}=\mathrm{a})$

Sudirman, Jenderal. 26 Maret 2010. 15 dari 42 Siswa Stres saat UN. Radar Tasikmalaya (http://www.radartasikmalaya.com/i ndex.php/option=com_content\&vie $\mathrm{w}=$ article\&id=980:15-dari-42-siswastres-saat-un).

Sugiyono. 2011. Metode Penelitian Pendidikan, Pendekatan Kuantitatif, Kualitatif, dan R\&D. Bandung: Alfabeta.

Susilo, Harry. 22 April 2009. Siswa Stres Hadapi Soal Matematika. Kompas.com (http://nasional.kompas.com/read/20 09/04/22/21180449/Siswa.Stres.Had api.Soal.Matematika).

Takwin, Bagus. 2008. Diri dan Pengelolaannya. Jurnal Psikologi Sosial. Jakarta. Fakultas Psikologis UI Jakarta.

Wisantyo, Nurmalitasari Indah. 2010. Stres pada Siswa SMAN 3 Semarang Ditinjau dari Efiksasi Diri Akademik dan Jenis Kelas. Skripsi tidak diterbitkan. Semarang. Fakultas Psikologi Universitas Diponegoro Semarang. (http://eprints.undip.ac.id/10959/1/ri ngkasan.pdf) 